\title{
Growth and Yield of Rice (Oryza sativa) as Influenced by Humic Acid and Poultry Manure
}

\author{
R Saha $^{1}$, M A U Saieed ${ }^{2, *}$, M A K Chowdhury ${ }^{3}$ \\ ${ }^{1}$ Department of Agricultural Chemistry, Bangladesh Agricultural University, Mymensingh \\ ${ }^{2}$ Department of Seed Science and Technology, Bangladesh Agricultural University, Mymensingh \\ ${ }^{3}$ Department of Agricultural Chemistry, Bangladesh Agricultural University, Mymensingh \\ *Corresponding Author: atiksst@gmail.com
}

Copyright () 2013 Horizon Research Publishing. All rights reserved.

\begin{abstract}
Humic acid (HA) and poultry manure (PM) were applied on T. aman rice cv. BRRI dhan39 to observe their effects on rice. Three levels of humic acid viz. 0, 3 and 6 $\mathrm{L} \mathrm{ha}^{-1}$ and three levels of poultry manure viz. 0,3 and $6 \mathrm{tha}^{-1}$ were applied along with recommended doses of N, P, K and $\mathrm{S}$ fertilizers from urea, TSP, MoP and gypsum, respectively following Randomized Complete Block Design (RCBD). Parameters used in the experiment were plant height, effective tillers hill ${ }^{-1}$, panicle length, no. of grains panicle ${ }^{-1}$, 1000 -grain weight, grain and straw yields. The application of different treatments showed positive trend in all the parameters of BRRI dhan39. The highest grain yield (4.07 t $\mathrm{ha}^{-1}$ ) was recorded by the application of $6 \mathrm{~L} \mathrm{ha}^{-1}$ humic acid along with $3 \mathrm{tha}^{-1}$ poultry manure which was identical with the application of $6 \mathrm{~L} \mathrm{ha}^{-1}$ humic acid along with $6 \mathrm{t} \mathrm{ha}^{-1}$ poultry manure but was different from other treatment combinations.
\end{abstract}

Keywords Humic Acid, Poultry Manure, Growth, Yield, BRRI Dhan39 Etc

\section{Introduction}

Rice is the main staple food of Bangladesh. About $80 \%$ of cropped area is used for rice cultivation, with annual production of 4,37,29,000 metric tons (IRRI, 2006). The average yield of rice in Bangladesh is $3.90 \mathrm{t} \mathrm{ha}^{-1}$ (BRRI, 2007) which is almost less than $50 \%$ of the world average yield. Continuous use of chemical fertilizers accelerated the depletion of soil organic matter and impairs physical and chemical properties of soil in addition to causing micronutrient deficiencies. In Bangladesh, most of the cultivated soils have less than $1.5 \%$ organic matter. This important component of soil is declining with time due to intensive cropping and use of higher doses of chemical fertilizers with little or no addition of manure. Humic acid is one of the major components of humic substances. Humic matter is formed through the chemical and biological humification of plant and animal matter and through the biological activities of microorganisms (Anonymous, 2010). The effects of humic substances on plant growth depend on the source and concentration, as well as on the molecular fraction weight of humus. Humic acid improves the physical, chemical and biological properties of the soil and influences plant growth by influencing the growth of roots. Initiation of root enhancement and increased root growth may be observed by the application of humic acids and fulvic acids to the soil (Pettit, 2004). The effects were directly correlated with enhanced uptake of macronutrients, such as nitrogen, phosphorus and sulfur, and micronutrients like $\mathrm{Fe}, \mathrm{Zn}, \mathrm{Cu}$ and Mn (Chen et al., 2001). Poultry manure is an excellent source of nutrients and can be incorporated into most fertilizer programs. Application of manures must be practiced sound soil fertility management to prevent nutrient imbalances and associated animal health risks as well as surface-water and groundwater contamination. Global environment pollution can also be reduced considerably by reducing the use of chemical fertilizers and increasing the use of cowdung, poultry manure, rice straw and others. Bangladesh agriculture has experienced multiple nutrient deficiencies over the years. For sustainable agriculture, a soil management strategy must be based on maintaining soil quality, which is only possible by utilization of high quality manures along with inorganic fertilizers.

\section{Materials and Methods}

\subsection{Experimental Site and Design}

The experiment was carried out during the Aman season from August to November, 2010 at Central Farm of Bangladesh Agricultural University, Mymensingh. The experiment was set up in a typical rice growing soil. Rice cultivar BRRI dhan39 was used as test crop. There were 9 treatments consisting of three rates of humic acid $(0,3$ and 6 $\left.\mathrm{L} \mathrm{ha}^{-1}\right)$ and three rates of poultry manure $\left(0,3\right.$ and $\left.6 \mathrm{tha}^{-1}\right)$. The treatments are $\mathrm{T}_{0}=\mathrm{HA}_{0}+\mathrm{PM}_{0}, \mathrm{~T}_{1}=\mathrm{HA}_{0}+\mathrm{PM}_{3}, \mathrm{~T}_{2}=$ 
$\mathrm{HA}_{0}+\mathrm{PM}_{6}, \mathrm{~T}_{3}=\mathrm{HA}_{3}+\mathrm{PM}_{0}, \mathrm{~T}_{4}=\mathrm{HA}_{3}+\mathrm{PM}_{3}, \mathrm{~T}_{5}=\mathrm{HA}_{3}+\mathrm{PM}_{6}$, $\mathrm{T}_{6}=\mathrm{HA}_{6}+\mathrm{PM}_{0}, \mathrm{~T}_{7}=\mathrm{HA}_{6}+\mathrm{PM}_{3}$ and $\mathrm{T}_{8}=\mathrm{HA}_{6}+\mathrm{PM}_{6}$. The experiment was laid out in a randomized complete block design with three replications.

\subsection{Data Collection and Statistical Analysis}

Land was prepared with power tiller and leveled with ladder. The unit plot size was $10 \mathrm{~m}^{2}$ (4.0 $\left.\mathrm{m} \times 2.5 \mathrm{~m}\right) .25$ days old seedlings were transplanted with the spacing of $15 \mathrm{~cm} \mathrm{x}$ $20 \mathrm{~cm}$. The doses of NPKS were as per the recommendations made by the Bangladesh Rice Research Institute (BRRI) and that was urea $150 \mathrm{~kg} \mathrm{ha}^{-1}\left(69 \mathrm{~kg} \mathrm{~N} \mathrm{ha}^{-1}\right)$, TSP $100 \mathrm{~kg} \mathrm{ha}^{-1}$, MoP $70 \mathrm{~kg} \mathrm{ha}^{-1}$ and gypsum $10 \mathrm{~kg} \mathrm{ha}^{-1}$. Intercultural operations were practiced as and when necessary. The crop was harvested on 17th November 2010. The plant threshed and grain and straw was collected plot-wise. Humic acid was collected from Global Agrovat Company Limited and poultry manure was collected from the Poultry Farm of Bangladesh Agricultural University, Mymensingh. Humic acid was used in liquid form. Data were collected on crop characters such as plant height, number of total tillers hill ${ }^{-1}$, number of effective tillers hill ${ }^{-1}$, panicle length, number of grains panicle $^{-1}$, number of filled grains panicle ${ }^{-1}, 1000$-grain weight, grain yield, straw yield, biological yield and harvest index. Data were statistically analyzed using the MSTAT statistical Computer Package Programme (Gomez and Gomez, 1984).

\section{Results and Discussion}

\subsection{Plant Height}

Plant height was significantly influenced by different doses of humic acid (Table 1). Humic acid produced the longest plant $(86.33 \mathrm{~cm})$ by the application of $3 \mathrm{~L} \mathrm{ha}^{-1}$ where the shortest plant height $(86.11 \mathrm{~cm})$ was obtained at control. Application of poultry manure did not significantly influence the plant height (Table 1). There was no significant interaction in plant height due to combined application of humic acid and poultry manure (Table 2). Plant height might be increased due to greater availability of nutrients which is also stated by Sivakumar et. al. (2007) and Nguyen et. al. (2004).

Table 1. The effect of humic acid and poultry manure on the yield attributes of T. aman rice cv. BRRI dhan39

\begin{tabular}{|c|c|c|c|c|c|c|c|}
\hline Treatments & $\begin{array}{c}\text { Plant } \\
\text { height }(\mathrm{cm})\end{array}$ & $\begin{array}{l}\text { Total tillers } \\
\text { hill }^{-1} \text { (No.) }\end{array}$ & $\begin{array}{c}\text { Effective tillers } \\
\text { hill }^{-1} \text { (No.) }\end{array}$ & $\begin{array}{l}\text { Panicle length } \\
(\mathrm{cm})\end{array}$ & $\begin{array}{c}\text { Total grains } \\
\text { panicle }^{-1} \text { (No.) }\end{array}$ & $\begin{array}{c}\text { Filled grains } \\
\text { panicle }^{-1} \text { (No.) }\end{array}$ & $\begin{array}{l}\text { 1000-grain } \\
\text { weight }(\mathrm{g})\end{array}$ \\
\hline $\mathrm{HA}_{0}$ & $86.11 \mathrm{c}$ & 10.33 & $8.56 \mathrm{c}$ & $23.43 b$ & $105.22 \mathrm{c}$ & $96.11 \mathrm{c}$ & $18.28 \mathrm{c}$ \\
\hline $\mathrm{HA}_{3}$ & $86.33 a$ & 11.56 & $10.78 \mathrm{a}$ & $24.50 \mathrm{ab}$ & $125.11 \mathrm{~b}$ & $116.00 \mathrm{~b}$ & $19.53 b$ \\
\hline $\mathrm{HA}_{6}$ & $86.22 b$ & 11.00 & $9.56 \mathrm{~b}$ & $24.78 \mathrm{a}$ & $148.78 \mathrm{a}$ & $137.56 \mathrm{a}$ & $20.16 a$ \\
\hline CV (\%) & 2.20 & 7.88 & 2.95 & 2.71 & 10.71 & 10.76 & 1.83 \\
\hline $\begin{array}{c}\text { Level of } \\
\text { significance }\end{array}$ & $*$ & NS & $* *$ & $* *$ & $* *$ & $* *$ & * \\
\hline $\mathrm{PM}_{0}$ & 85.44 & $10.22 b$ & $9.00 \mathrm{~b}$ & 23.78 & $113.78 b$ & $106.67 b$ & $19.04 \mathrm{c}$ \\
\hline $\mathrm{PM}_{3}$ & 86.44 & $11.00 \mathrm{ab}$ & $9.78 \mathrm{ab}$ & 24.43 & $114.00 \mathrm{~b}$ & $104.11 b$ & $19.39 b$ \\
\hline $\mathrm{PM}_{6}$ & 86.78 & $11.67 \mathrm{a}$ & $10.11 \mathrm{a}$ & 24.50 & $151.33 \mathrm{a}$ & $138.89 \mathrm{a}$ & $19.53 \mathrm{a}$ \\
\hline CV (\%) & 4.32 & 6.41 & 2.95 & 23.36 & 0.81 & 1.99 & 6.41 \\
\hline $\begin{array}{c}\text { Level of } \\
\text { significance }\end{array}$ & NS & $*$ & $*$ & NS & $* *$ & $* *$ & $* *$ \\
\hline
\end{tabular}

Legends: HA $=$ Humic acid, PM= Poultry manure, $*=$ Significant at $5 \%$ level of probability, $* *=$ Significant at $1 \%$ level of probability, NS= Not significant. 
Table 2. The interaction effects of humic acid and poultry manure on the yield attributes of T. aman rice cv. BRRI dhan39

\begin{tabular}{|c|c|c|c|c|c|c|c|}
\hline Treatments & $\begin{array}{l}\text { Plant height } \\
(\mathrm{cm})\end{array}$ & $\begin{array}{l}\text { Total tillers } \\
\text { hill }^{-1} \text { (No.) }\end{array}$ & $\begin{array}{l}\text { Effective tillers } \\
\text { hill }^{-1} \text { (No.) }\end{array}$ & $\begin{array}{l}\text { Panicle length } \\
\text { (cm ) }\end{array}$ & $\begin{array}{c}\text { Total grains } \\
\text { panicle }^{-1} \text { (No.) }\end{array}$ & $\begin{array}{l}\text { Filled grains } \\
\text { panicle }^{-1} \text { (No.) }\end{array}$ & $\begin{array}{l}\text { 1000-grain } \\
\text { weight }(\mathrm{g})\end{array}$ \\
\hline $\mathrm{HA}_{0} \mathrm{PM}_{0}$ & 85.33 & $10.00 \mathrm{c}$ & $8.33 \mathrm{c}$ & 23.33 & $82.67 \mathrm{e}$ & $79.00 \mathrm{f}$ & $17.67 \mathrm{~d}$ \\
\hline $\mathrm{HA}_{0} \mathrm{PM}_{3}$ & 87.67 & $10.33 c$ & $8.67 \mathrm{~b}$ & 23.44 & $98.67 d$ & $90.67 \mathrm{e}$ & $18.33 \mathrm{c}$ \\
\hline $\mathrm{HA}_{0} \mathrm{PM}_{6}$ & 85.33 & $10.67 \mathrm{bc}$ & $8.67 b$ & 23.50 & $134.33 \mathrm{c}$ & $118.67 \mathrm{c}$ & $18.83 \mathrm{c}$ \\
\hline $\mathrm{HA}_{3} \mathrm{PM}_{0}$ & 84.00 & $10.33 c$ & $9.67 \mathrm{~b}$ & 23.33 & $120.67 \mathrm{c}$ & $113.33 \mathrm{c}$ & $19.53 b$ \\
\hline $\mathrm{HA}_{3} \mathrm{PM}_{3}$ & 86.67 & $12.00 \mathrm{ab}$ & $11.33 \mathrm{a}$ & 25.17 & $114.33 \mathrm{~cd}$ & $104.33 d$ & $19.57 \mathrm{~b}$ \\
\hline $\mathrm{HA}_{3} \mathrm{PM}_{6}$ & 88.33 & $12.33 \mathrm{a}$ & $10.33 \mathrm{a}$ & 25.00 & $140.33 b$ & $130.33 b$ & $19.50 \mathrm{~b}$ \\
\hline $\mathrm{HA}_{6} \mathrm{PM}_{0}$ & 85.00 & $10.67 \mathrm{bc}$ & $9.33 b$ & 24.67 & $129.00 \mathrm{c}$ & $117.33 \mathrm{c}$ & $20.27 \mathrm{a}$ \\
\hline $\mathrm{HA}_{6} \mathrm{PM}_{3}$ & 86.67 & $12.00 \mathrm{ab}$ & $11.33 \mathrm{a}$ & 25.00 & $179.33 \mathrm{a}$ & $167.67 \mathrm{a}$ & $20.27 \mathrm{a}$ \\
\hline $\mathrm{HA}_{6} \mathrm{PM}_{6}$ & 87.00 & $10.33 \mathrm{c}$ & $9.00 \mathrm{~b}$ & 24.67 & $138.00 \mathrm{c}$ & $127.67 \mathrm{c}$ & $19.93 \mathrm{ab}$ \\
\hline CV(\%) & 4.32 & 6.41 & 2.95 & 2.71 & 10.71 & 10.76 & 1.83 \\
\hline $\begin{array}{l}\text { Level of } \\
\text { significance }\end{array}$ & NS & $* *$ & $* *$ & NS & $* *$ & $* *$ & $*$ \\
\hline
\end{tabular}

Legends: HA = Humic acid, PM= Poultry manure, $*=$ Significant at $5 \%$ level of probability, $* *=$ Significant at $1 \%$ level of probability, NS $=$ Not significant.

\subsection{Total Tillers Hill ${ }^{-1}$}

Total number of tillers hill ${ }^{-1}$ was not significantly influenced by the application of humic acid (Table 1). The highest number of tillers hill ${ }^{-1}$ (11.67) was produced by the application of $6 \mathrm{t} \mathrm{ha}^{-1} \mathrm{PM}$ and the lowest $(10.22)$ was obtained at control. This result was partially supported by Miller (2007) and Bhattacharya et al. (2003). Total number of tillers hill ${ }^{-1}$ was significantly affected by the interaction effect of humic acid and poultry manure (Table 2). The highest number of tillers hill' ${ }^{-1}$ (12.33) was obtained in $T_{5}$ which was statistically similar to $\mathrm{T}_{4}$ and $\mathrm{T}_{7}$. This increase in number of tillers hill ${ }^{-1}$ was perhaps due to the addition of humic acid and poultry manure which promote nitrogen supply which is essential for vegetative growth.

\subsection{Effective Tillers Hill ${ }^{-1}$}

Humic acid and poultry manure both had significant effect on the number of effective tillers hill ${ }^{-1}$ (Table 1). The highest result (10.78) was obtained when humic acid was applied @ $3 \mathrm{~L} \mathrm{ha}^{-1}$ and the lowest (8.56) was produced at $\mathrm{HA}_{0}$. The highest number of effective tillers hill $^{-1}$ (10.11) was produced when poultry manure was applied @ $6 \mathrm{t} \mathrm{ha}^{-1}$ and the lowest number of effective tillers hill $^{-1}$ (9.00) was produced at control. Organic sources offer more balanced nutrition to plants, especially micro nutrients which has caused better affectivity of tiller in plants grown with poultry manure and vermicompost (Miller, 2007). This result was also partially supported by Rakshit et al. (2008). There was a significant difference in the total number of effective tillers hill $^{-1}$ due to the interaction effect of humic acid and poultry manure (Table 2). The highest number of effective tillers hill $^{-1}$ (11.33) was obtained in the interaction of humic acid and poultry manure in $T_{7}$ treatment where humic acid and poultry manure were applied @ $6 \mathrm{~L} \mathrm{ha}^{-1}$ and $3 \mathrm{t} \mathrm{ha}^{-1}$, respectively and the lowest (8.33) was obtained at $\mathrm{T}_{0}$.

\subsection{Panicle Length}

A significant difference in panicle length was obtained with the application of humic acid (Table 1). The longest panicle length $(24.78 \mathrm{~cm})$ was obtained with humic acid applied@6 L ha ${ }^{-1}$ and the shortest $(23.43 \mathrm{~cm}$ ) was obtained at control. The loss of nitrogen is less in presence of humic acid which helps in vegetative growth such as panicle length of rice plant. This finding was similar with the 
observation made by Mishra and Srivastava (1988). The application of poultry manure did not significantly influence the panicle length (Table 1). There was no significant difference in panicle length due to interaction effect of humic acid and poultry manure (Table 2 ).

\subsection{Total Number of Grains Panicle ${ }^{-1}$}

Total number of grains panicle ${ }^{-1}$ was significantly increased by the application of humic acid (Table 1). The highest number of grains panicle ${ }^{-1}(148.78)$ was found with the application of humic acid @ $6 \mathrm{~L} \mathrm{ha}^{-1}$ and lowest (105.22) at control. It was noticed that humic acid induced positive effect on total number of grains panicle ${ }^{-1}$. The application of poultry manure also significantly increased the total number of grains panicle ${ }^{-1}$ (Table 1). The highest number of grains panicle $^{-1}$ (151.33) was obtained with the application of poultry manure@ $@ \mathrm{t} \mathrm{ha}^{-1}$ and it was the lowest (113.78) at $\mathrm{PM}_{0}$. The total number of grains panicle ${ }^{-1}$ was augmented significantly due to interaction effect of different levels of humic acid and poultry manure (Table 2). The highest (179.33) was obtained in the interaction effect of humic acid and poultry manure in $\mathrm{T}_{7}$ treatment and the lowest (82.67) was obtained at $\mathrm{T}_{0}$. Hasanuzzaman et al. (2010) also reported similar results.

\subsection{Number of Filled Grains Panicle ${ }^{-1}$}

Application of humic acid extensively influenced the number of filled grains panicle ${ }^{-1}$ (Table 1). Humic acid produced significantly the highest number of filled grains panicle $^{-1}$ (137.56) when applied @ $6 \mathrm{~L} \mathrm{ha}^{-1}$ and the lowest (96.11) was obtained at control. Humic acid helps in uptake of phosphorus as phosphorus enhances fruiting of plant. Nottidge et al., (2005) stated the similar opinion. The number of filled grains panicle ${ }^{-1}$ was significantly increased by the application of poultry manure at higher dose but at lower dose it did not have any positive effect (Table). The highest number of filled grains panicle ${ }^{-1}$ (138.89) was obtained by the application of $6 \mathrm{t} \mathrm{ha}^{-1} \mathrm{PM}$ and the lowest (106.67) was recorded at $T_{0}$. Interaction of different levels of humic acid and poultry manure had positive influence on rice (Table 2). The highest number of filled grains panicle ${ }^{-1}$ (167.67) was obtained in the interaction of humic acid and poultry manure in $T_{7}$ treatment and the lowest (79.00) was recorded at $\mathrm{T}_{0}$.

\subsection{Total Number of Grains Panicle ${ }^{-1}$}

Total number of grains panicle ${ }^{-1}$ was significantly increased by the application of humic acid (Table 1). The highest number of grains panicle ${ }^{-1}$ (148.78) was found with the application of humic acid @ $6 \mathrm{~L} \mathrm{ha}^{-1}$ and lowest (105.22) at control. It was noticed that humic acid induced positive effect on total number of grains panicle ${ }^{-1}$. The application of poultry manure also significantly increased the total number of grains panicle ${ }^{-1}$ (Table 1). The highest number of grains panicle $^{-1}$ (151.33) was obtained with the application of poultry manure@ $6 \mathrm{t} \mathrm{ha}^{-1}$ and it was the lowest (113.78) at $\mathrm{PM}_{0}$. The total number of grains panicle ${ }^{-1}$ was augmented significantly due to interaction effect of different levels of humic acid and poultry manure (Table 2). The highest (179.33) was obtained in the interaction effect of humic acid and poultry manure in $\mathrm{T}_{7}$ treatment and the lowest (82.67) was obtained at $\mathrm{T}_{0}$.

\subsection{0-Grain Weight}

The 1000-grain weight was significantly influenced by the application of humic acid (Table 1). The highest 1000-grain weight $(20.16 \mathrm{~g})$ was obtained when humic acid was applied (a) $6 \mathrm{~L} \mathrm{~h} \mathrm{ha}^{-1}$ and it was lowest (18.28g) in control treatment. The application of poultry manure exaggerated 1000-grain weight significantly (Table 1). The highest 1000-grain weight was obtained (19.53g) when poultry manure was applied@6 tha ${ }^{-1}$ and the lowest (19.04g) was found in control treatment. The interaction effect of humic acid and poultry manure had significant influence on 1000-grain weight (Table 2). The highest 1000-grain weight (20.27g) was obtained in $T_{7}$ which was similar with $T_{6}$ and it was lowest $(17.67 \mathrm{~g})$ in $\mathrm{T}_{0}$. Dhanasekaran and Govindasamy (2002) reported that availability of nutrients during reproductive stage helped for better grain filling and as a result grain weight was increased.

\subsection{Grain Yield}

The yield of grain of BRRI dhan39 was considerably influenced by the application of humic acid (Table 3). The highest grain yield $\left(3.20 \mathrm{t} \mathrm{ha}^{-1}\right)$ was obtained when humic acid was applied @ $6 \mathrm{~L} \mathrm{ha}^{-1}$ and the lowest $\left(3.09 \mathrm{t} \mathrm{ha}^{-1}\right)$ was in control. Humic acid influenced the nutrition and growth of plants in an indirect manner. It might also influence the plant growth directly either through its effects on ion uptake or by more direct effects on the growth regulation of the plant (Vaughan and Linehan, 1976). The application of poultry manure increased the grain yield significantly (Table 3 ). The highest grain yield $\left(3.42 \mathrm{t} \mathrm{ha}^{-1}\right)$ was obtained when poultry manure was applied @ $6 \mathrm{t} \mathrm{ha}^{-1}$ and the lowest $\left(2.90 \mathrm{t} \mathrm{ha}^{-1}\right)$ was found in control. The results suggest that poultry manure offered better nutritional quality and favorable balance of nutrients when supplemented with NPK which provided the maximum yield. Rakshit et al. (2008) also observed similar findings. The combined application of humic acid and poultry manure induced higher the grain yield significantly (Table 4). The highest grain yield $\left(4.07 \mathrm{tha}^{-1}\right)$ was obtained in $\mathrm{T}_{7}$ treatment and the lowest grain yield $\left(2.37 \mathrm{t} \mathrm{ha}^{-1}\right)$ was found in $\mathrm{T}_{0}$ treatment. 
Table 3. The effect of humic acid and poultry manure on the yield attributes of T. aman rice cv. BRRI dhan39

\begin{tabular}{|c|c|c|c|c|c|}
\hline Treatments & $\begin{array}{l}\text { Grain yield } \\
\left(\mathrm{t} \mathrm{ha}^{-1}\right)\end{array}$ & $\begin{array}{c}\text { Grain yield increase over } \\
\text { control (\%) }\end{array}$ & $\begin{array}{l}\text { Straw yield } \\
\left(\mathrm{t} \mathrm{ha}^{-1}\right)\end{array}$ & $\begin{array}{c}\text { Straw yield increase over } \\
\text { control }(\%)\end{array}$ & $\begin{array}{c}\text { Harvest } \\
\text { Index (\%) }\end{array}$ \\
\hline $\mathrm{HA}_{0}$ & $3.09 \mathrm{~b}$ & 0 & $8.22 b$ & 0 & $23.32 b$ \\
\hline $\mathrm{HA}_{3}$ & $3.10 \mathrm{ab}$ & $0.32 b$ & $8.33 b$ & $1.34 \mathrm{~b}$ & $27.09 \mathrm{a}$ \\
\hline $\mathrm{HA}_{6}$ & $3.20 \mathrm{a}$ & $3.56 \mathrm{a}$ & $8.45 \mathrm{a}$ & $2.78 \mathrm{a}$ & $27.46 \mathrm{a}$ \\
\hline CV (\%) & 7.18 & 1.23 & 1.94 & 0.94 & 5.46 \\
\hline Level of significance & $*$ & $* *$ & $* *$ & $* *$ & $* *$ \\
\hline $\mathrm{PM}_{0}$ & $2.90 \mathrm{~b}$ & 0 & $8.20 \mathrm{~b}$ & 0 & $25.34 \mathrm{c}$ \\
\hline $\mathrm{PM}_{3}$ & $3.06 \mathrm{ab}$ & $5.52 \mathrm{~b}$ & $9.06 \mathrm{ab}$ & $10.49 \mathrm{~b}$ & $26.07 b$ \\
\hline $\mathrm{PM}_{6}$ & $3.42 \mathrm{a}$ & $17.93 \mathrm{a}$ & $9.25 \mathrm{a}$ & $12.80 \mathrm{a}$ & $27.06 \mathrm{a}$ \\
\hline CV (\%) & 0.81 & 2.34 & 1.99 & 1.07 & 23.36 \\
\hline $\begin{array}{l}\text { Level of } \\
\text { significance }\end{array}$ & $* *$ & $* *$ & $*$ & $* *$ & $* *$ \\
\hline
\end{tabular}

Legends: HA = Humic acid, PM= Poultry manure, $*=$ Significant at $5 \%$ level of probability, $* *=$ Significant at $1 \%$ level of probability, NS $=$ Not significant.

Table 4. The interaction effects of humic acid and poultry manure on the yield attributes of T. aman rice cv. BRRI dhan39

\begin{tabular}{|c|c|c|c|c|c|}
\hline Treatments & $\begin{array}{l}\text { Grain yield } \\
\left(\mathrm{t} \mathrm{ha}^{-1}\right)\end{array}$ & $\begin{array}{c}\text { Grain yield increase over } \\
\text { control (\%) }\end{array}$ & $\begin{array}{l}\text { Straw yield } \\
\left(\mathrm{t} \mathrm{ha}^{-1}\right)\end{array}$ & $\begin{array}{c}\text { Straw yield increase over } \\
\text { control }(\%)\end{array}$ & Harvest index (\%) \\
\hline $\mathrm{HA}_{0} \mathrm{PM}_{0}$ & $2.37 \mathrm{~d}$ & 0 & $7.98 \mathrm{f}$ & 0 & $22.89 \mathrm{bc}$ \\
\hline $\mathrm{HA}_{0} \mathrm{PM}_{3}$ & $2.97 \mathrm{c}$ & $25.32 \mathrm{~d}$ & $10.00 \mathrm{~b}$ & $25.31 \mathrm{~b}$ & $22.89 \mathrm{c}$ \\
\hline $\mathrm{HA}_{0} \mathrm{PM}_{6}$ & 2.98 & $25.74 d$ & $10.01 \mathrm{a}$ & $25.44 b$ & $22.94 c$ \\
\hline $\mathrm{HA}_{3} \mathrm{PM}_{0}$ & $3.00 \mathrm{bc}$ & $26.58 \mathrm{~cd}$ & $8.10 \mathrm{e}$ & $1.50 \mathrm{f}$ & $27.02 \mathrm{a}$ \\
\hline $\mathrm{HA}_{3} \mathrm{PM}_{3}$ & $3.05 \mathrm{bc}$ & $28.69 \mathrm{c}$ & $8.77 \mathrm{c}$ & $9.90 \mathrm{~d}$ & $25.78 b$ \\
\hline $\mathrm{HA}_{3} \mathrm{PM}_{6}$ & $3.23 b$ & $36.29 b$ & $8.23 \mathrm{de}$ & $3.13 \mathrm{ef}$ & $28.18 \mathrm{a}$ \\
\hline $\mathrm{HA}_{6} \mathrm{PM}_{0}$ & $3.17 \mathrm{~b}$ & $33.76 \mathrm{bc}$ & $8.29 \mathrm{~d}$ & $3.88 \mathrm{e}$ & $27.66 \mathrm{a}$ \\
\hline $\mathrm{HA}_{6} \mathrm{PM}_{3}$ & $4.07 \mathrm{a}$ & $71.73 \mathrm{a}$ & $10.28 \mathrm{a}$ & $28.82 \mathrm{a}$ & $28.36 \mathrm{a}$ \\
\hline $\mathrm{HA}_{6} \mathrm{PM}_{6}$ & $3.34 b$ & $40.93 b$ & $9.46 \mathrm{c}$ & $18.55 \mathrm{c}$ & $26.09 a$ \\
\hline $\mathrm{CV}(\%)$ & 0.81 & 4.78 & 1.99 & 3.93 & 5.46 \\
\hline $\begin{array}{l}\text { Level of } \\
\text { significance }\end{array}$ & $* *$ & $* *$ & $* *$ & $* *$ & $* *$ \\
\hline
\end{tabular}

Legends: HA = Humic acid, PM= Poultry manure, $*=$ Significant at $5 \%$ level of probability, $* *=$ Significant at $1 \%$ level of probability, NS $=$ Not significant. 


\subsection{Grain Yield Increase over Control}

The percent grain yield increase over control was influenced by the application of humic acid (Table 3 ). The grain yield increased $0.32 \%$ when humic acid was applied @ $3 \mathrm{~L} \mathrm{ha}^{-1}$ and 3.56\% when applied @ $6 \mathrm{~L} \mathrm{ha}^{-1}$. The application of poultry manure also exerted increased percent grain yield over control (Table 3). The grain yield increased was $17.93 \%$ when poultry manure was applied @ $6 \mathrm{t} \mathrm{ha}^{-1}$ and it was $5.52 \%$ when it was applied @ $3 \mathrm{tha}^{-1}$. The percent grain yield increase over control was due to combined application of humic acid and poultry manure (Table 4). The highest grain yield increased $71.73 \%$ in $\mathrm{T}_{7}$ treatment where humic acid and poultry manure were applied @ $6 \mathrm{~L} \mathrm{ha}^{-1}$ and $3 \mathrm{tha}^{-1}$, respectively and it was lowest $(25.32 \%)$ in $\mathrm{T}_{2}$ treatment.

\subsection{Straw Yield}

The straw yield was significantly influenced by the application of humic acid (Table 3 ). The highest straw yield $\left(8.45 \mathrm{tha}^{-1}\right)$ was obtained when humic acid was applied @6 $\mathrm{L} \mathrm{ha}^{-1}$ and the lowest $\left(8.22 \mathrm{t} \mathrm{ha}^{-1}\right)$ was in $\mathrm{HA}_{0}$. The application of poultry manure increased the straw yield appreciably (Table 3). The highest straw yield $\left(9.25 \mathrm{t} \mathrm{ha}^{-1}\right)$ was obtained when poultry manure was applied @ $6 \mathrm{t}$ $\mathrm{ha}^{-1}$ and the lowest $\left(8.20 \mathrm{tha}^{-1}\right)$ was obtained in control. An expressive effect was observed with the combined application of humic acid and poultry manure which augmented the straw yield significantly (Table 4). The highest straw yield $\left(10.28 \mathrm{t} \mathrm{ha}^{-1}\right)$ was obtained when humic acid and poultry manure were applied @ $6 \mathrm{~L} \mathrm{ha}^{-1}$ and $3 \mathrm{tha}^{-1}$, respectively and the lowest $\left(7.98 \mathrm{t} \mathrm{ha}^{-1}\right)$ was found in $\mathrm{T}_{0}$ treatment.

\subsection{Straw Yield Increase over Control}

The percent straw yield increase over control was significantly influenced by the application of humic acid (Table 3). Straw yield increased $1.34 \%$ when humic acid was applied@3 L ha ${ }^{-1}$ and 2.78\% when it was applied@6 L ha ${ }^{-1}$. Application of poultry manure also increased the percent straw yield over control (Table 3). Straw yield increased $10.49 \%$ when poultry manure was applied @ $3 \mathrm{t} \mathrm{ha}^{-1}$ and it was $12.80 \%$ when it was applied @ $6 \mathrm{t} \mathrm{ha}^{-1}$. The percent straw yield increase over control was also influenced due to combined application of humic acid and poultry manure (Table 4). The highest straw yield increased $28.82 \%$ in $\mathrm{T}_{7}$ treatment where humic acid and poultry manure were applied @ $6 \mathrm{~L} \mathrm{ha}^{-1}$ and $3 \mathrm{tha}^{-1}$, respectively and it was lowest $(1.50 \%)$ when humic acid and poultry manure were applied (a) $3 \mathrm{~L} \mathrm{ha}^{-1}$ and $0 \mathrm{tha}^{-1}$, respectively.

\subsection{Harvest Index}

The application of humic acid significantly influenced harvest index (Table 3$)$. The highest HI $(27.46 \%$ ) was found when humic acid was applied @ $6 \mathrm{~L} \mathrm{ha}^{-1}$ and the lowest HI $(23.32 \%)$ was found at control. Harvest indices were appreciably varied with the application of different doses of poultry manure (Table 3 ). The highest HI $(27.06 \%)$ was found when poultry manure was applied @ $6 \mathrm{tha}^{-1}$ and the lowest $(25.34 \%)$ was found at control. It might be due to better grain yield with corresponding biological yield. Channabasavanna and Biradar (2001) stated the similar opinion. The highest $\mathrm{HI}$ with $6 \mathrm{tha}^{-1}$ poultry manure was due to more economic yield caused by more availability of nutrients. The combined application of humic acid and poultry manure significantly influenced $\mathrm{HI}$ (Table 4 ). The highest $\mathrm{HI}(28.36 \%)$ was recorded at treatment $\mathrm{T}_{7}$ and the lowest HI (22.89\%) was found at control.

\section{Conclusion}

Yield contributing characters were significantly influenced by different treatment combinations of HA and PM along with chemical fertilizers and became maximum when humic acid and poultry manure were applied @6 L $\mathrm{ha}^{-1}$ and $3 \mathrm{tha}^{-1}$, respectively. The highest grain yield (4.07 t $\left.\mathrm{ha}^{-1}\right)$ and straw yield $\left(10.28 \mathrm{tha}^{-1}\right)$ was found in $\mathrm{T}_{7}$ treatment and that was lowest $\left(2.37 \mathrm{t} \mathrm{ha}^{-1}\right.$ and $\left.7.98 \mathrm{t} \mathrm{ha}^{-1}\right)$ at control, respectively. However, application of PM @ $3 \mathrm{t} \mathrm{ha}^{-1}$ along with HA@6 L ha ${ }^{-1}$ showed better performance than PM or $\mathrm{HA}$ alone. It is therefore concluded that the incorporation of HA @ 6 L ha $^{-1}$ plus PM@ 3 tha $^{-1}$ with recommended doses of NPKS could be used for obtaining higher yield of $\mathrm{T}$. aman rice particularly BRRI dhan39.

\section{REFERENCES}

[1] Anonymous. 2010. Humic and fulvic acids: The black gold of agriculture? [Available at

http://www.humintech.com/pdf/humicfulvicacids.pdf]

[2] Bhattacharya, S. P., Sitangshu S., Karmakar, A. J., Bera, P. S. and Latika, M. 2003. Effects of humic acid (Earth) on the growth and yield of transplanted summer rice. Environ. Ecol.; 21(3): 680-683.

[3] BRRI (Bangladesh Rice Research Institute). 2007. Bangladesh Rice Knowledge Bank. [Available at http://riceknowledgebank.brri.org.]

[4] Channabasavanna, A. S. and Biradar, P. D. 2001. Response of irrigated rice to the application of poultry manure and inorganic fertilizer N, P and $\mathrm{K}$ in Karnataka, India. Int. Rice Res. News; 26(2): 64-65.

[5] Chen, Y., Magen, H. and Clapp, C. E. 2001. Plant growth stimulation by humic substances and their complexes with iron. Proc. Intl. Fer. Soc., Israel. p.14.

[6] Dhanasekaran, K. and Govindasamy, R. 2002. Effect of urea coated with lignite derived humic substances on the performance of rice in a Typic Chromustert soil. Adv. Plant 
Sci.; 15(2): 505-509.

[7] Gomez, K. A. and Gomez, A. A. 1984. Statistical Procedures for Agricultural Research. Intl. Rice Res. Inst; John Wiley and Sons. New York, Chickester, Brisbane, Toronto, Singapore. p. 680.

[8] Hasanuzzaman, M., Ahamed, K. U., Nahar, K. and Akhter, N. 2010. Plant growth pattern, tiller dynamics and dry matter accumulation of wetland rice (Oryza sativa L.) as influenced by application of different manures. Nature Sci.; 8(4):1-10.

[9] IRRI (International Rice Research Institute). 2006. World Rice Statistics. Intl. Rice Res. Inst. [Available at http://www.irri.org/science/wrs.]

[10] Miller, H. B. 2007. Poultry litter induces tillering in rice. J. Sus. Agric.; 31:1-12.

[11] Mishra, B. and Srivastava, L. L. 1988. Physiological properties of humic acids isolated from some major soil associations of Bihar. J. Indian Soc. Soil Sci.; 36: 83-89.

[12] Nguyen, B. V., Olk, D. C. and Cassman, K. G. 2004. Nitrogen Mineralization from Humic Acid Fractions in Rice
Soils- Depends on Degree of Humification. Faculty Publications - Agronomy \& Horticulture.

[13] Nottidge, D. O., Ojeniyi, S. O. and Asawalam, D. O. 2005. Comparative effects of plant residues and NPK fertilizer on soil properties in a humid Ultisol. Nig. J. Soil Sci.; 15: 9-13.

[14] Pettit, R. E. 2004. Organic matter, humus, humate, humic acid, fulvic acid and humin: Their importance in soil fertility and plant health. [Available at http://www.humate.info/main page.htm.]

[15] Rakshit, A.; Sarkar, N. C. and Sen, D. 2008. Influence of organic manures on productivity of two varieties of rice. J. Cent. Eur. Agric.; 9:629-634.

[16] Sivakumar, K., Devarajan, L., Dhanasekaran, K., Venkatakrishnan, D. and Surendran, U. 2007. Effect of humic acid on the yield and nutrient uptake of rice. ORYZAAn International Journal on Rice; 44 (3): 277 - 279.

[17] Vaughan, D. and Linehan, D. J. 1976. The growth of wheat plants in humic acid solutions under axenic conditions. Plant Soil; 44: 445-499. 